\title{
BANK VERSUS STOCK MARKET DEVELOPMENT IN BRAZIL: AN ARDL BOUNDS TESTING APPROACH
}

Sheilla Nyasha, Nicholas M. Odhiambo

\section{Abstract}

This paper examines the impact of both bank-based and market-based financial development on economic growth in Brazil during the period from 1980 to 2012. To incorporate all of the aspects of financial development into the regression analysis, the study employs a method of means-removed average to construct both bank-based and market-based financial development indices. Based on the ARDL approach, the empirical results show that there is a positive relationship between market-based financial development and economic growth in Brazil in the long run, but not in the short run. The results also show that bank-based financial development in Brazil does not have a positive effect on economic growth. This applies irrespective of whether the regression analysis is conducted in the short run, or in the long run. The study, therefore, concludes that it is the stock market, rather than banking sector development, that drives long-run economic growth in Brazil. Keywords: Brazil, Bank-Based Financial Development, Market-Based Financial Development, Economic Growth

JEL classification: $G 10, G 20,016$

\section{INTRODUCTION}

The relationship between banking sector development, stock market development and economic growth has generated a considerable amount of debate in recent years. This debate still rages on to this date - but with little consensus. A growing body of work reveals the close relationship between financial development and economic growth (Gelb 1989, Roubini and Sala-i-Martin 1992, King and Levine 1993a, 1993b). However, alternative views exist. Early works lending support to the positive relationship between financial development and economic growth include those of Schumpeter (1911), Goldsmith (1969), McKinnon (1973), Shaw (1973), King and Levine (1993a) and Odedokun (1996), among others. Studies that support a negative relationship include Van Wijnbergen (1983) and Buffie (1984); while studies by Robinson (1952), Lucas (1988) and Stern (1989), among others, either found no association, or a negligible relationship, between financial development and economic growth.

Previous studies on this subject, however, suffer from four major limitations. First, the majority of the

Sheilla Nyasha, DCOM

Senior Researcher

Department of Economics, University of South Africa E-mail: sheillanyasha@gmail.com

Nicholas M. Odhiambo, PhD

Professor and Research Chair of Macroeconomic Policy Analysis Programme

Department of Economics, University of South Africa E-mail: Odhianm@unisa.ac.za 
previous studies relied mainly on bank-based proxies of financial development, giving market-based proxies little attention. Where latter studies have been undertaken, the empirical findings have been inconclusive (Levine and Zervos 1996, Akinlo and Akinlo 2009, Ujunwa and Salami 2010); evidence suggests that the outcome is proxy-dependent and country-dependent.

Second, the majority of the previous studies have mainly used either the residual-based co-integration test associated with Engle and Granger (1987), or the maximum-likelihood test (Johansen 1988, Johansen and Juselius 1990). Yet it is now well known that these co-integration techniques may not be appropriate when the sample size is too small (see Odhiambo 2009). Third, some of the previous studies over-relied on cross-sectional data, which may not have satisfactorily addressed country-specific issues (Ghirmay 2004, Casselli et al. 1996). Fourth, the bulk of the previous studies have mainly been based on the causal relationship between financial development and economic growth. Very few studies have examined in detail the relative impact of both bank-based and market-based financial development on economic growth.

It is against this backdrop that the current study attempts to examine the relative effect of bank-based and market-based financial development on economic growth in Brazil, using the newly developed autoregressive distributed lag (ARDL) bounds testing approach. In order to incorporate the various proxies of bank-based and market-based financial development in the empirical analysis, the current study employs a method of means-removed average to construct both bank-based and market-based financial development indices.

The rest of this paper is organised as follows: Section 2 gives an overview of the financial sector reforms and development in Brazil. Section 3 highlights the theoretical and empirical linkages between bankbased and market-based financial development and economic growth. Section 4 presents the empirical model specification, the estimation technique, and the empirical analysis of the regression results. Section 5 concludes the study.

\section{FINANCIAL SECTOR REFORMS IN BRAZIL}

While the Brazilian financial system is diverse, complex and characterised by a high degree of conglomeration, concentration, and public sector presence, its banking system is less globally integrated compared to its peer countries, while the opposite is true for its equity markets (International Monetary
Fund 2013). Today, Brazil has several stock exchanges, which have gradually emerged over the years, and which have also gradually acquired one another and/ or merged over the years to form one stock exchange: the BM\&FBovespa, which is one of the world's largest stock exchanges.

Over the years, the Brazilian financial sector, both the banking sector and the stock market, has been exposed to a number of reforms. The late 1980 s marked the commencement of banking sector reform in Brazil. The reforms were wide-ranging in scope, and included programmes for: creating specialised financial institutions; restructuring private sector and state-controlled banks; and the decision to allow foreign banks entry into the national financial system (Carneiro et al. 1993). On the stock market side, amongst the reforms was the restructuring of the financial market, which came with the enactment of new laws and the revision of existing laws governing the stock market (Ministry of Finance, Brazil 2012). Thus the stock market reforms in Brazil have addressed the legal, regulatory, judiciary and supervisory aspects of the business, as well as general modernisation of the trading environment.

The rigorous reforms over time have given rise to an improved financial system in Brazil. In the banking sector, banking sector reforms undertaken in Brazil since the late 1980s saw the beginning of the evolution of the Brazilian bank-based financial system, leading to changes in how banks operate, and a subsequent increase in the number of banks. The growth of the Brazilian banking system is also evidenced by growth in private sector credit; low levels of non-performing loans; and an improvement in legal rights (World Bank 2012). Figure 1 illustrates the trends in banking sector growth, as shown by credit extension to the private sector (CPS) in Brazil during the period 1975-2013.

In the stock market, these reforms gave rise to an increased number of listed companies - from 394 listed companies at Bovespa in 2006 to 594 in 2012 (BM\&F Bovespa 2012); and a modest increase in stock market capitalisation, total value traded and turnover ratio (World Bank 2012). Figure 2 tracks the performance and growth of the Brazilian Stock Market during the period 1988-2012.

Despite this growth, the country's financial system still faces some challenges. These include coping with constraints on budget and human resources; ensuring adequate legal protection; a rise in non-performing loans; cuts in lending rates; still-prevalent shortterm indexation; still-low liquidity in the secondary market; and managing the role of Brazil's National Development Bank (BNDES) (Park 2012). 
Figure 1: Trends in Banking Sector Growth and Economic Growth in Brazil (1975-2012)

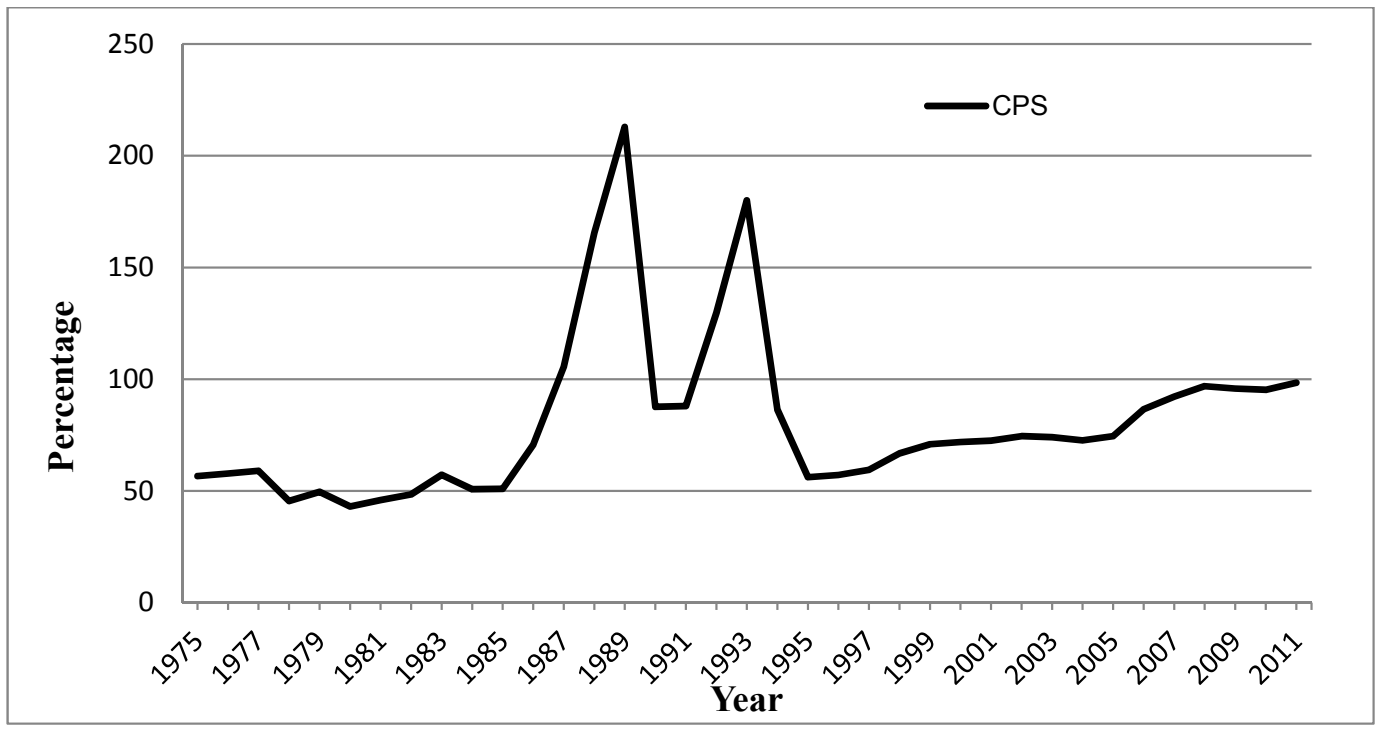

Source: World Bank (2014)

Figure 2: Trends in Stock Market Capitalisation, Total Value of Stocks Traded and Turnover Ratio of Stocks Traded in Brazil (1988-2012)

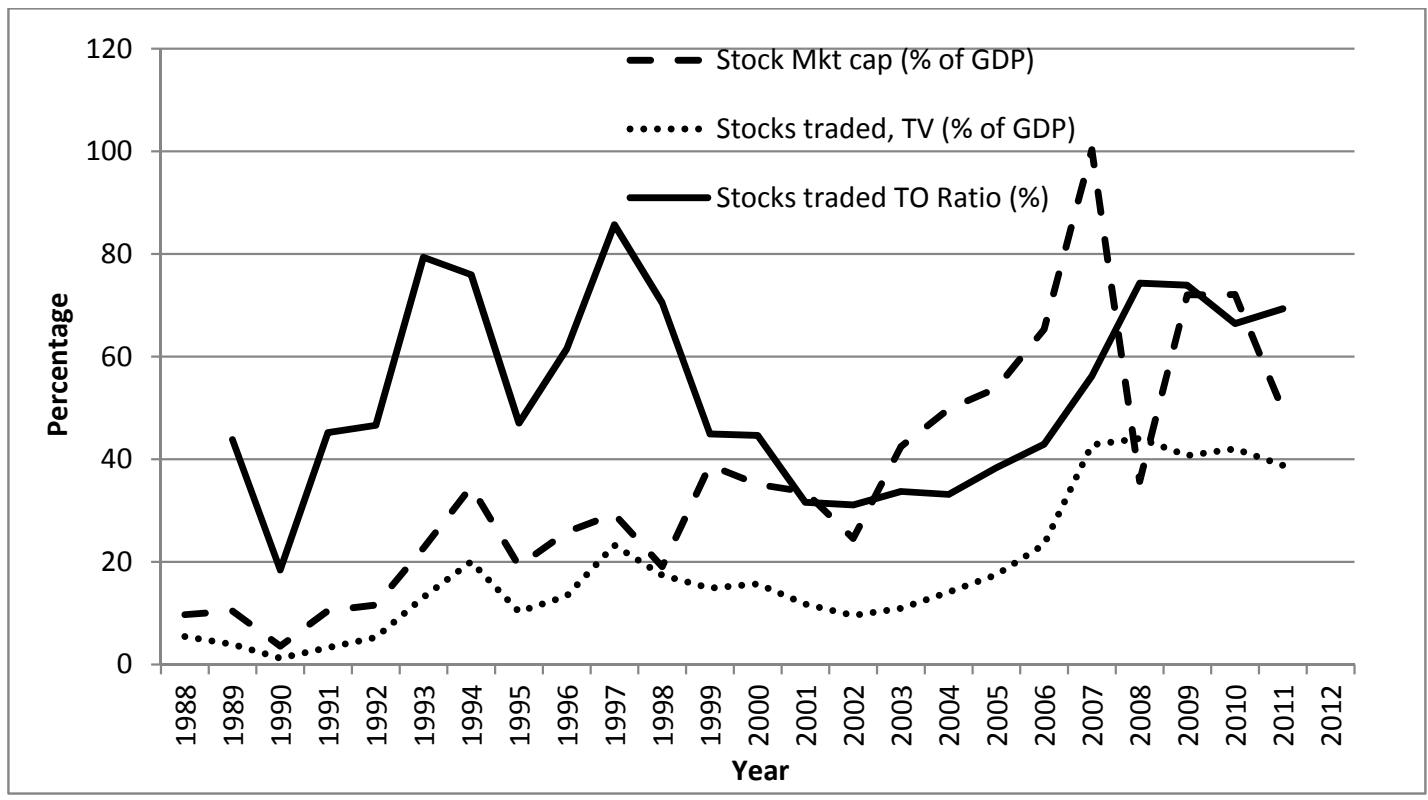

Source: World Bank (2014)

3. BANK-BASED FINANCIAL DEVELOPMENT, MARKET-BASED FINANCIAL DEVELOPMENT AND ECONOMIC GROWTH: A REVIEW OF LITERATURE

Generally, a financial system is made up of a bankbased component and a market-based component. According to Demirguc-Kunt and Levine (2001), if an economy is driven by financial intermediaries more than it is driven by financial markets, that economy's financial system is generally referred to as "a bankbased financial system". However, if securities markets share centre stage with banks in driving economic growth via savings mobilisation and allocation, exerting corporate control, and easing risk management, the financial system is generally referred to as "a market-based financial system". It is still believed, by most, that a bank-based financial system is better than a market-based system. In particular, Hoshi et al. (1990) argued that economic growth could be encouraged 
more in the bank-based system; since it can induce longer-term investment in the real sector, whereas investment in the market-based system is too sensitive to stock market prices with short-term investment.

The bank-based system can encourage productive investment, as it is less affected by unstable financial markets (Hoshi et al., 1990). Moreover, it is argued that expensive government policies can be carried out more easily in the bank-based system, because it provides governments with more measures to intervene in the financial sector than the market-based system (Pollin 1995). Proponents of the bank-based systems add that, without powerful banks to enforce repayment, external investors would be reluctant to finance industrial expansion in countries with underdeveloped institutions. Thus, if banks are not hampered by regulatory restrictions on their activities, they can exploit economies of scale in information processing, moral hazard amelioration through effective monitoring, and in the formation of long-run relationships with firms to ease asymmetric information distortions, thereby boosting economic growth.

However, the bank-based financial system is not without its own disadvantages. According to Allen and Gale (1999), banks may not be effective gatherers and processors of information, in new, uncertain situations involving innovative products and processes (Allen and Gale 1999). This has prompted some to lend support to a market-based financial system, arguing that markets provide a richer set of risk-management tools that permit greater customisation of risk-ameliorating instruments. According to Levine (2004), as economies mature and need a richer set of risk-management tools and vehicles for raising capital, they may concomitantly benefit from a legal and regulatory environment that supports the evolution of market-based activities - otherwise, overall growth may be retarded (Levine 2004).

The relationship between financial development and economic growth has received widespread attention in the empirical growth literature. Although it is now well recognised that bank-based financial development is positively associated with economic growth, inconsistencies in this conclusion still exist. While some studies attest to the existence of a positive relationship between bank-based financial development and economic growth (see Odedokun 1996, Ahmed and Ansari 1998, Christopoulos and Tsionas 2004, Nazmi 2005, Güryay et al. 2007, Kar, Peker, and Kaplan 2008, Kargbo and Adamu 2009, Yonezawa Azeez 2010, Awojobi 2013, Gambacorta et al. 2014, Oludele, Akinboade, and Chanceline 2015); other studies, although few, conclude that there is a negative relationship between bank-based financial development and economic growth (see De Gregorio and Guidotti 1995, Bolbol et al. 2005).

Regarding market-based financial development, just as with bank-based financial development and economic growth, some authors have shown a positive link between market-based financial development and economic growth (see, among others, Fama 1990), while others have argued that even large stock markets are unimportant sources of corporate finance (Mayer 1988). Although some economists have generally emphasised the central role of financial markets in economic growth, the empirical evidence on the relationship between market-based financial development and economic growth is apparently both scant and inconclusive. Some of the studies that have examined the relationship between stock market development and economic growth include those by Levine and Zervos (1996), Caporale et al. (2003), Bekaert et al. (2005), Adjasi and Biekpe (2006), Nurudeen (2009), Akinlo and Akinlo (2009), Ujunwa and Salami (2010), Bernard and Austin (2011), Masoud and Hardaker (2012) and Gambacorta et al. (2014). These studies found a positive relationship between market-based financial development and economic growth, as opposed to studies by Ujunwa and Salami (2010) and Bernard and Austin (2011) that found evidence of a positive association for some countries, and a negative association in others.

\section{MODEL SPECIFICATION, ESTIMATION TECHNIQUES AND EMPIRICAL ANALYSIS}

\subsection{Model Specification}

The empirical model used in this study to test the impact of financial development, both bank-based and market-based, on economic growth is based on Ram (1999), Christopoulos and Tsionas (2004), Majid (2008), and Kargbo and Adamu (2009). The model can be specified as follows:

$G D P_{t}=\alpha_{0}+\alpha_{1} B F D_{t}+\alpha_{2} M F D_{t}+\alpha_{3} I N V_{t}+$
$\alpha_{4} S A V_{t}+\alpha_{5} T O P_{t}+\varepsilon_{t} \ldots \ldots \ldots \ldots \ldots \ldots \ldots \ldots \ldots \ldots \ldots \ldots \ldots \ldots \ldots \ldots \ldots \ldots$

Where:

GDP (a proxy for economic $(G D P)=$ annual growth rate of real gross domestic product;

$\mathrm{BFD}=$ bank-based financial development index;

MFD = market-based financial development index;

INV = investment;

SAV = savings; and

TOP $=$ trade openness 
The dynamic impact of bank-based and marketbased financial development on economic growth in this study is re-examined using the autoregressive distributed lag bounds testing approach to cointegration analysis. Various measures have been used in the literature to proxy for economic growth and the "level of financial development". This section outlines the theoretical underpinnings of the general empirical model and subsequently presents the empirical model.

In this study, the annual growth rate of real gross domestic product is used as a proxy for economic growth (GDP). This proxy has been used extensively in the literature (see, among others, Wood 1993, Odedokun 1996, Shan and Jianhong 2006, Majid 2008).

On the other hand, financial development is proxied by bank-based and market-based financial indicators. Bank-based financial development is proxied by a bank-based financial development index (BFD) that is constructed from three bank-based financial development variables - namely, M2 to nominal GDP (M2), $M 3$ to nominal GDP (M3), and domestic credit to private sector divided by nominal GDP (C). Market-based financial development is proxied by a market-based financial development index (MFD) that is constructed from three market-based financial development variables - namely, stock market capitalisation (CAP), total value of stocks traded (TV), and turnover ratio (TOR).

In modern literature, bank-based financial development is proxied by various indicators. However, for this study, the first variable used is the ratio of $M 2$ to GDP, which measures the overall size of the financial intermediary in a country (see Levine 1993a, Levine 1997, Calderon and Liu 2003). A higher ratio of M2 to GDP shows a larger financial sector and, consequently, larger financial intermediation. The opposite is also true. The second variable is the ratio M3 to GDP. This variable reflects the change in liquidity of the banking sector in relation to time (Ghali 1999). An increase in M3 to GDP can be taken as progress in an economy's financial sector.

However, M2 and M3 alone can be rendered as inadequate measures of financial development, according to Ang and McKibbin (2007), because of the availability of foreign funds in the financial system. As such, credit provided to the private sector by financial intermediaries expressed as a percentage of GDP (C) often claimed to be a more superior measure of financial development - has been used as well in this study. Since the private sector is able to utilise funds in a more efficient and productive manner as compared to the public sector, the exclusion of credit to the public sector better reflects the extent of efficient resource allocation (Ang and McKibbin 2007).
According to Ang and McKibbin (2007), these variables are highly correlated in most cases, yet there is no uniform argument as to which proxies are most appropriate for measuring financial development. This justifies the need for constructing an index as a single measure that represents overall development in the bank-based financial sector by taking the relevant financial proxies into account.

Thus, this study uses M2 to nominal GDP (M2), M3 to nominal GDP (M3), and domestic credit to private sectors divided by nominal GDP (C) as the proxies for bank-based financial development. Consequently, in order to produce an assessment of the overall level of "bank development" in Brazil, an index of bank-based financial development that averages together the information contained in the three individual indicators is produced. Following Demirguc-Kunt and Levine (1996), an index of bank-based financial development (BFD) is constructed using these three variables.

To compute a conglomerate index of bank-based financial development, the means-removed values of the three indicators of bank development are averaged in a two-step procedure. First, the meansremoved values of $M 2, M 3$, and $C$ are computed. The means-removed value of variable $X$ is defined as $X m$ $=[X-$ mean $(X)] /[A B S($ mean $(X))]$, where $A B S(z)$ refers to the absolute value of $z$. Second, a simple average of the means-removed $M 2, M 3$, and $C$ is taken to obtain an overall index of bank-based financial development (BFD).

Market-based financial development is proxied by a market-based financial development index (MFD) that is constructed from three market-based financial development variables - namely, stock market capitalisation (CAP), total value of stocks traded (TV), and turnover ratio (TOR).

As with the dilemma encountered when choosing indicators for bank-based financial development, there is no best indicator for market-based financial development. However, the most commonly used are the three given above. Although many stock market development indicators are significantly correlated in an intuitively plausible fashion, the individual indicators produce different country rankings. Thus, to produce an assessment of the overall level of "stock market development" in a country, an index that averages together the information contained in the individual indicators is developed.

The first indicator of market-based financial development used in this study is market capitalisation ratio, calculated as the value of listed shares divided by GDP (CAP). Analysts frequently use this ratio as a measure of stock market size. In terms of economic significance, the assumption behind market capitalisation is 
that market size is positively correlated with the ability to mobilise capital and diversify risk. The second indicator of market-based financial development utilised is the total value traded as a ratio of GDP, calculated as total shares traded on the stock market exchange divided by GDP (TV). The total value traded ratio measures the organised trading of equities as a share of national output. As a result, it is expected to positively reflect liquidity in an economy. Together, market capitalisation and total value traded gives a picture of stock market size and liquidity.

The third indicator of market-based financial development used in this study, which also happens to be the second measure of liquidity, is the turnover ratio (TOR), which is equal to the value of total shares traded divided by market capitalisation. High turnover often reflects low transaction costs. Turnover complements the total value of stocks traded/GDP as well. However, total value traded/GDP captures trading in relation to the size of the economy, while turnover measures trading relative to stock market size. As such, a small but liquid market will have a small total value traded/ GDP ratio and a high turnover ratio.

Thus, incorporating information on market capitalisation, total value traded/GDP and turnover provides a more comprehensive picture of market-based financial development than the information provided by any single indicator. Therefore, a conglomerate index of market-based financial development (MFD) is computed using the same procedure for constructing a conglomerate index of bank-based financial development (BFD), as discussed above. Bank-based and market-based financial development are expected to exert a positive impact on economic growth; hence, their coefficients are expected to be positive.

In addition to the real GDP growth rate (GDP) and the financial development indicators (BFD and MFD), three other variables have been introduced in the model. These additional variables comprise the share of investment in GDP, the share of savings in GDP, and trade openness. These three variables have been included in the above model to fully specify the model. According to growth theory, the three additional variables exert a positive impact on economic growth; hence, their coefficients are also expected to be positive.

Investment in this study is calculated as gross fixed capital formation as a share of GDP (INV). According to Abu-Bader and Abu-Qarn (2008), this variable is considered to be one of the few economic variables with a robust correlation to economic growth, regardless of the information set. According to economic growth literature, investment is supposed to lead to economic growth; hence, its coefficient is expected to be positive.

The second control variable used is savings, calculated as savings as a share of GDP. The choice of savings ratio as an additional variable has to a large extent been influenced by the theoretical links between savings and economic growth. Traditional theories such as those suggested by Solow (1956), Romer (1986), and Lucas (1988) have emphasised the role of savings in economic growth. Solow (1956), for example, argues that an increase in savings generates higher growth in the short run during the transition between steady states (also see Odhiambo 2008). According to endogenous growth models developed by Romer (1986) and Lucas (1988), a permanent increase in growth can be determined by higher savings and capital accumulation. Following the argument above, savings as a share of GDP (SAV) has been chosen as one of the variables, and its coefficient is expected to be positive.

The third control variable utilised is trade openness (TOP). The positive relationship between trade and economic growth is well documented in the literature. Recent literature shows that trade openness and economic growth are related (Ang and McKibbin 2007). This variable has been included in order to capture the role of trade liberalisation in economic growth. The degree of openness is found by adding imports and exports as a percentage of GDP, and, in this case, its coefficient is expected to be positive and statistically significant.

\subsection{Co-integration - ARDL Bounds Testing Procedure}

This study utilises the newly proposed autoregressive-distributed lag (ARDL) bounds testing approach originally introduced by Pesaran and Shin (1999), and later extended by Pesaran et al. (2001) to examine the co-integration relationship between bank-based and market-based financial development and economic growth. The choice of this test is based on the numerous advantages it has over previous co-integration tests, such as the residual-based technique by Engle and Granger (1987), and the Full-Maximum Likelihood (FML) test based on Johansen $(1988,1991)$, and on Johansen and Juselius (1990).

First, while other co-integration techniques are sensitive to the size of the sample, the ARDL test is suitable even when the sample size is small. Thus, the ARDL test has superior small sample properties when compared to the Johansen and Juselius (1990) co-integration test (Pesaran and Shin 1999). Second, unlike other conventional co-integration techniques, 
the ARDL bounds testing approach does not impose the restrictive assumption that all the variables under study must be integrated of the same order. In other words, the ARDL approach can be applied to test the existence of a relationship between variables - regardless of whether the underlying regressors are integrated of order one [I(1)], order zero [I(0)], or fractionally integrated. Third, while conventional co-integration methods estimate the long-run relationship within the context of a system of equations, the ARDL method employs only a single reduced form equation (Pesaran and Shin 1999). Fourth, the ARDL technique generally provides unbiased estimates of the longrun model and valid t statistics - even when some of the regressors are endogenous (Odhiambo 2008, Odhiambo 2011). Therefore, the approach is considered to be very suitable for analysing the underlying relationship, and it has been increasingly used in empirical research in recent years.

Following Pesaran et al. (2001), the ARDL representation of the model used in this study can be expressed as follows:

$$
\begin{aligned}
\Delta G D P_{t}=\alpha_{0} & +\sum_{i=1}^{n} \alpha_{1 i} \Delta G D P_{t-i}+\sum_{i=0}^{n} \alpha_{2 i} \Delta B F D_{t-i} \\
& +\sum_{i=0}^{n} \alpha_{3 i} \Delta M F D_{t-i}+\sum_{i=0}^{n} \alpha_{4 i} \Delta I N V_{t-i} \\
& +\sum_{i=0}^{n} \alpha_{5 i} \Delta S A V_{t-i}+\sum_{i=0}^{n} \alpha_{6 i} \Delta T O P_{t-i} \\
& +\sigma_{1} G D P_{t-1}+\sigma_{2} B F D_{t-1} \\
& +\sigma_{3} M F D_{t-1}+\sigma_{4} I N V_{t-1} \\
& +\sigma_{5} S A V_{t-1}+\sigma_{6} T O P_{t-1}+\gamma D \\
& +\mu_{t} \cdots \cdots \cdots \cdots \cdots \cdots \cdots \cdots \cdots \cdots \cdots \cdots \cdots \cdots \cdots \cdots \cdots \cdots
\end{aligned}
$$

Where GDP is the growth rate of real gross domestic product (a proxy for economic growth), BFD is an index of bank-based financial development, which is a means-removed average of $M 2, M 3$ and credit provided to the private sector by financial intermediaries - a proxy for bank-based financial development (see also Demirguc-Kunt and Levine 1996); MFD is an index of market-based financial development, which is a means-removed average of stock market capitalisation, stock market traded value and stock market turnover - a proxy for market-based financial development (see also Demirguc-Kunt and Levine 1996); INV is a share of the investment in GDP; SAV is a share of savings in GDP; TOP is trade openness; $D$ is a financial reform dummy; $\alpha_{0}$ is a constant, $\alpha_{1}-\alpha_{6} ; \sigma_{1}-\sigma_{6}$ and $\gamma$ are regression coefficients, $\Delta$ is the difference operator, $\mathrm{n}$ is the lag length and $\mu_{t}$ is the white noise-error term.

The error correction model is specified as follows:

$$
\begin{aligned}
& \Delta G D P_{t} \\
& =\alpha_{0} \\
& +\sum_{i=1}^{n} \alpha_{1 i} \Delta G D P_{t-i}+\sum_{i=0}^{n} \alpha_{2 i} \Delta B F D_{t-i}+\sum_{i=0}^{n} \alpha_{3 i} \Delta M F D_{t-i} \\
& +\sum_{i=0}^{n} \alpha_{4 i} \Delta I N V_{t-i}+\sum_{i=0}^{n} \alpha_{5 i} \Delta S A V_{t-i}+\sum_{i=0}^{n} \alpha_{6 i} \Delta T O P_{t-i}+\gamma \Delta D \\
& +\xi_{1} E C M_{t-1} \\
& +\mu_{t} \ldots \ldots \ldots \ldots \ldots \ldots \ldots \ldots \ldots \ldots \ldots \ldots \ldots \ldots \ldots \ldots \ldots \ldots \ldots \ldots \ldots \ldots \ldots \ldots \ldots \ldots \ldots \ldots \ldots \ldots \ldots \ldots
\end{aligned}
$$

\subsection{Data Sources}

This study utilised annual time-series data covering the period from 1980 to 2012. The annual data used in the study were obtained from the World Bank Economic Indicators (World Bank 2014), except for the market-based financial development proxies (stock market capitalisation, stock market traded value, and stock market turnover) for the period 1980 to 1988, which were obtained from the Emerging Stock Markets Factbook, 1991 (International Finance Corporation 1991). All the model estimations were computed using Microfit 5.0 software.

\subsection{Stationarity Tests}

Before any analysis was performed, the variables were first tested for stationarity, using the Dickey-Fuller generalised least-square (DF-GLS) and the PhillipsPerron (PP) tests. To accommodate the possibility of structural breaks within the dataset, the Perron (1997) test for unit root (PPURoot) was also utilised as the third unit-root testing method.

The DF-GLS lag length was selected automatically by SIC; the PP truncation lag was selected automatically on the Newey-West bandwidth; and the PPURoot break years were also automatically selected. These dates ranged from 1986 to 2004, depending on the variable (see Appendix 1). The results of DF-GLS, PP and the PPU-Root stationarity tests for all the variables are presented in Table 1.

The results reported in Table 1 show that after differencing the variables once, all the variables were confirmed to be stationary. Even though the ARDL test does not require the pre-testing of variable, the unitroot test provides guidance as to whether ARDL is applicable, as it is only applicable for the analysis of variables that are integrated of order zero [I(0)] or order one [(1)]. In this instance, the variables are a mixture 
Table 1: Stationarity Tests of all Variables

\begin{tabular}{|c|c|c|c|c|}
\hline \multicolumn{5}{|c|}{ Dickey-Fuller generalised least square (DF_GLS) } \\
\hline \multirow[t]{2}{*}{ Variable } & \multicolumn{2}{|c|}{ Stationarity of all Variables in Levels } & \multicolumn{2}{|c|}{$\begin{array}{l}\text { Stationarity of all Variables in First } \\
\text { Difference }\end{array}$} \\
\hline & Without Trend & With Trend & Without Trend & With Trend \\
\hline GDP & $-4.197^{* * *}$ & $-5.013^{* * *}$ & - & - \\
\hline BFD & -1.897 & -2.169 & $-6.690 * * *$ & $-6.742 * * *$ \\
\hline MFD & -0.926 & $-3.194^{* *}$ & $-7.387^{* * *}$ & $-7.419 * * *$ \\
\hline INV & $-1.978^{* *}$ & -2.264 & $-5.105^{* * *}$ & $-4.164^{* * *}$ \\
\hline SAV & $-3.061^{* * *}$ & $-3.101^{*}$ & - & - \\
\hline TOP & -1.176 & -2.133 & $-5.004^{* * *}$ & $-5.115^{* * *}$ \\
\hline \multicolumn{5}{|c|}{ Phillips - Perron (PP) } \\
\hline \multirow[t]{2}{*}{ Variable } & \multicolumn{2}{|c|}{ Stationarity of all Variables in Levels } & \multicolumn{2}{|c|}{$\begin{array}{l}\text { Stationarity of all Variables in First } \\
\text { Difference }\end{array}$} \\
\hline & Without Trend & With Trend & Without Trend & With Trend \\
\hline GDP & $-5.697^{* * *}$ & $-5.851^{* * *}$ & - & - \\
\hline BFD & $-2.907^{*}$ & -2.670 & $-7.179 * * *$ & $-7.094^{* * *}$ \\
\hline MFD & -1.115 & -3.178 & $-7.367^{* * *}$ & $-7.237^{* * *}$ \\
\hline INV & -2.495 & -2.245 & $-5.152^{* * *}$ & $-5.514^{* * *}$ \\
\hline SAV & $-3.030^{* *}$ & -2.982 & $-8.611^{* * *}$ & $-8.439 * * *$ \\
\hline TOP & -1.209 & -2.412 & $-4.968^{* * *}$ & $-4.948^{* * *}$ \\
\hline \multicolumn{5}{|c|}{ Perron, 1997 (PPURoot) } \\
\hline \multirow[t]{2}{*}{ Variable } & \multicolumn{2}{|c|}{ Stationarity of all Variables in Levels } & \multicolumn{2}{|c|}{$\begin{array}{l}\text { Stationarity of all Variables in First } \\
\text { Difference }\end{array}$} \\
\hline & Without Trend & With Trend & Without Trend & With Trend \\
\hline GDP & -4.822 & -4.540 & $-6.952^{* * *}$ & $-6.775^{* * *}$ \\
\hline BFD & -3.671 & -3.353 & $-6.541^{* * *}$ & $-6.461^{* * *}$ \\
\hline MFD & -3.494 & -3.436 & $-7.604^{* * *}$ & $-7.849^{* * *}$ \\
\hline INV & -3.455 & -3.252 & $-6.695^{* * *}$ & $-7.800^{* * *}$ \\
\hline SAV & -4.913 & -4.736 & $-6.725^{* * *}$ & $-6.963^{* * *}$ \\
\hline TOP & -4.040 & -3.690 & $-6.400^{* * *}$ & $-6.657^{* * *}$ \\
\hline
\end{tabular}

Notes: ${ }^{*}{ }^{* *}$ and ${ }^{* *}$ denote stationarity at $10 \%, 5 \%$ and $1 \%$ significance levels respectively.

of those integrated of order 0 , and of those integrated of order 1 . Therefore, the ARDL bounds testing procedure can be performed.

\subsection{Co-integration and ARDL-ECM Model}

In this section, the ARDL bounds testing procedure is used to examine the long-run relationship between the variables in the general model. The first step is to get the order of lags on the first differenced variables in equations (1) by using the Akaike Information
Criterion (AIC) and the Schwartz Bayesian Criterion (SIC). This is followed by the application of a bounds F-test to equation (1) to establish a long-run relationship between the variables under study. The results of the bounds F-test are reported in Table 2 .

The results of the $F$ test suggest that a long-run relationship between GDP, BFD, MFD, INV, SAV and TOP exists. Following the estimation of the ARDL model and the use of AIC or SIC for optimal lag-length selection, the SIC based ARDL $(1,1,1,1,0,1,0)$ model is selected because it is more parsimonious than the AIC-based model. The long-run results of the selected 
Table 2: Model 1: Bounds F-test for Co-integration

\begin{tabular}{|c|c|c|c|c|c|c|}
\hline Dependent Variable & \multicolumn{4}{|c|}{ Function } & \multicolumn{2}{|c|}{ F-statistic } \\
\hline$\Delta \mathrm{GDP}$ & \multicolumn{4}{|c|}{ F(GDP|BFD, MFD, INV, SAV,TOP,D) } & \multicolumn{2}{|c|}{$4.127^{* *}$} \\
\hline \multicolumn{7}{|c|}{ Asymptotic Critical Values } \\
\hline \multirow{3}{*}{$\begin{array}{l}\text { Pesaran et al. (2001), } \\
\text { p.300, Table Cl(iii) } \\
\text { Case III }\end{array}$} & \multicolumn{2}{|l|}{$1 \%$} & \multicolumn{2}{|l|}{$5 \%$} & \multicolumn{2}{|l|}{$10 \%$} \\
\hline & $\mathrm{I}(0)$ & $\mathrm{I}(1)$ & $\mathrm{I}(0)$ & $\mathrm{I}(1)$ & $\mathrm{I}(0)$ & $\mathrm{I}(1)$ \\
\hline & 3.15 & 4.43 & 2.45 & 3.61 & 2.12 & 3.23 \\
\hline
\end{tabular}

Note: ${ }^{* *}$ denotes statistical significance at $5 \%$ level.

Table 3: Results of the ARDL Model

Panel A: Long-run coefficients - Dependent variable is GDP

\begin{tabular}{|l|c|c|c|c|}
\hline Regressor & Co-efficient & Standard Error & T-Ratio & Prob \\
\hline C & $19.11^{* * *}$ & 4.84 & 3.95 & 0.001 \\
\hline BFD & 0.00 & 0.0 & 1.32 & 0.202 \\
\hline MFD & $0.05^{*}$ & 0.03 & 1.87 & 0.076 \\
\hline INV & $-0.98^{* * *}$ & 0.21 & -4.61 & 0.000 \\
\hline SAV & $0.20^{* *}$ & 0.09 & 2.10 & 0.048 \\
\hline TOP & -0.08 & 0.08 & -0.93 & 0.365 \\
\hline D & $-2.61^{*}$ & 1.40 & -1.87 & 0.076 \\
\hline
\end{tabular}

Panel B: ECM - Dependent variable is $\triangle \mathrm{GDP} ; \Delta=$ first difference operator

\begin{tabular}{|l|c|c|c|c|}
\hline Regressor & Co-efficient & Standard Error & T-Ratio & Prob \\
\hline$\Delta$ BFD & -0.00 & 0.00 & -1.12 & 0.272 \\
\hline$\Delta$ MFD & -0.05 & 0.05 & -0.90 & 0.377 \\
\hline$\Delta$ INV & 0.22 & 0.26 & 0.85 & 0.405 \\
\hline$\Delta$ SAV & $0.26^{*}$ & 0.13 & 2.02 & 0.054 \\
\hline$\Delta$ TOP & $-0.52^{* * *}$ & 1.19 & -2.78 & 0.010 \\
\hline$\Delta D$ & $-3.48^{*}$ & 1.84 & -1.89 & 0.071 \\
\hline ecm(-1) & $-0.69^{* * *}$ & 0.13 & -6.76 & 0.000 \\
\hline
\end{tabular}

\begin{tabular}{|llll}
\hline R-Squared & 0.889 & R-Bar-Squared & 0.828 \\
SE of Regression & 1.186 & F-Stat F $(7,24)$ & $22.8603[0.000]$ \\
Residual Sum of Squares & 74.419 & DW statistic & 2.156 \\
Akaike Info. Criterion & -70.910 & Schwarz Bayesian Criterion & -79.704
\end{tabular}

Notes: $1 .{ }^{*}{ }^{* *}$ and ${ }^{* *}$ denotes stationarity at $10 \%, 5 \%$ and $1 \%$ significance levels.

2. $\Delta \mathrm{GDP}=\mathrm{GDP}-\mathrm{GDP}(-1) ; \quad \triangle \mathrm{BFD}=\mathrm{BFD}-\mathrm{BFD}(-1) ; \quad \Delta \mathrm{MFD}=\mathrm{MFD}-\mathrm{MFD}(-1) ; \quad \Delta \mathrm{INV}=\mathrm{INV}-\mathrm{INV}(-1)$; $\triangle \mathrm{SAV}=\mathrm{SAV}-\mathrm{SAV}(-1) ; \Delta \mathrm{TOP}=\mathrm{TOP}-\mathrm{TOP}(-1) ; \Delta \mathrm{D}=\mathrm{D}-\mathrm{D}(-1)$; (see also Pesaran and Pesaran, 2009: 311; 506-507).

model are reported in Table 3 Panel A, and the results of the ECM are reported in Table 3 Panel B.

The long-run regression results have shown that the coefficient of market-based financial development is statistically significant and has a positive sign, as expected. These results imply that in Brazil an increase in the level of market-based financial development leads to an increase in economic growth in the long run.
The results displayed in Table 3 (Panel A) further reveal that in Brazil, bank-based financial development does not have an impact on economic growth, in the long run. This is evidenced by the coefficient of bankbased financial development, which is statistically insignificant. Based on these results, it can be concluded that Brazil's economic performance is positively related to market-based financial development and that 
market-based financial development plays a vital role in the economic performance of Brazil. These results are consistent with the results of Adjasi and Biekpe (2006), Nurudeen (2009) and Akinlo and Akinlo (2009), among others.

Other long-run results also show that the coefficient of investment (INV) is statistically significant but has an unexpected negative sign. Increase in investment in Brazil is detrimental to the economic growth process of the country in the long run. The coefficient of savings (SAV) is statistically significant and has an expected positive sign. Thus an increase in savings in Brazil leads to an increase in the country's economic growth. Trade openness (TOP) has a statistically insignificant coefficient. The financial liberalisation dummy (D) is statistically significant, but has an unexpected positive sign. This implies that liberalisation of the Brazilian financial sector is detrimental to economic growth in the long run.

The short-run dynamics of the model are reported in Table 3 (Panel B). The coefficients of bank-based financial development ( $\triangle B F D)$ and market-based financial development $(\triangle M F D)$ are insignificant, giving evidence of no relationship between bank-based financial development and economic growth, and between market-based financial development and economic growth, in Brazil, in the short run. The coefficient of investment is also insignificant. The coefficient of savings (SAV) is statistically significant and has an expected positive sign. This implies that, in Brazil, an increase in saving will lead to an improvement in economic growth in the short run. The coefficients of trade openness (TOP) and financial liberalisation dummy (D) are statistically significant but have unexpected negative signs. They show that in Brazil, an increase in trade openness leads to a drop in economic growth in the short run, and that in the short run financial liberalisation harms the economic growth process. The coefficient of ECM(-1) is statistically highly significant at the $1 \%$ significance level. Its negative sign is also expected, as it confirms the existence of a long-run relationship between the variables.

Although the Brazilian banking sector is one of the most developed banking sectors in Latin America, this study has found no significant impact of bank-based financial development on economic growth in Brazil. This could be because market-based financial development in Brazil has a more significant impact on economic growth than its bank-based counterpart, so that when both variables are incorporated into the growth equation, banking sector development becomes insignificant in the long run. Alternatively, the small sample size, prompted by the unavailability of sufficiently long-term time-series data for some key variables, could be the reason for the observed negligible impact of bank-based financial development on economic growth in Brazil.

Based on the empirical results of this study, market-based financial sector development was found to stimulate economic growth, though only in the long run. Thus, the policy implication is that for the Brazilian economy, immense efforts in promoting the development of the stock market are recommended in order to stimulate the real sector.

The regression for the underlying ARDL model fits well, as indicated by an R squared of $88.9 \%$. Model diagnostic tests displayed in Table 4 show that the model passes all the diagnostic tests performed against serial correlation, functional form, normality and heteroscedasticity.

Table 4: ARDL - VECM Diagnostic Tests

\begin{tabular}{|l|c|}
\hline LM Test Statistic & Results \\
\hline Serial Correlation: CHSQ(1 & $0.334[0.564]$ \\
\hline Functional Form: CHSQ(1) & $0.174[0.677]$ \\
\hline Normality: CHSQ(2) & $0.728[0.695]$ \\
\hline Heteroscedasticity: CHSQ(1 & $0.576[0.448]$ \\
\hline
\end{tabular}

The plots of Cumulative Sum of Recursive Residual (CUSUM) and Cumulative Sum of Squares of Recursive Residual (CUSUMQ) reported in Figures 3 and 4 show that both the CUSUM and CUSUMQ are within the boundaries. This shows that the long-run coefficients of the regressors are stable.

\subsection{Limitations of the Study}

Despite the efforts to make this study analytically defensible, it suffers from a few limitations, as is the case with many other scientific research studies. First, the study may suffer from the problem of insufficient data. The choice of annual data from 1980 to 2012 for empirical investigation was dictated by the availability of macroeconomic data. Unfortunately, stock market data are not readily available for a longer period. Although the use of an ARDL approach might have lessened the problem of data insufficiency, it may also be argued that a longer research period could affect the results. Moreover, the use of annual data in this study could have reduced the precision of the parameter estimates. In studies of this nature, quarterly data are more desirable. However, given that quarterly data for most of the variables in the study country were 
Figure 3: Plot of cumulative sum of recursive residuals

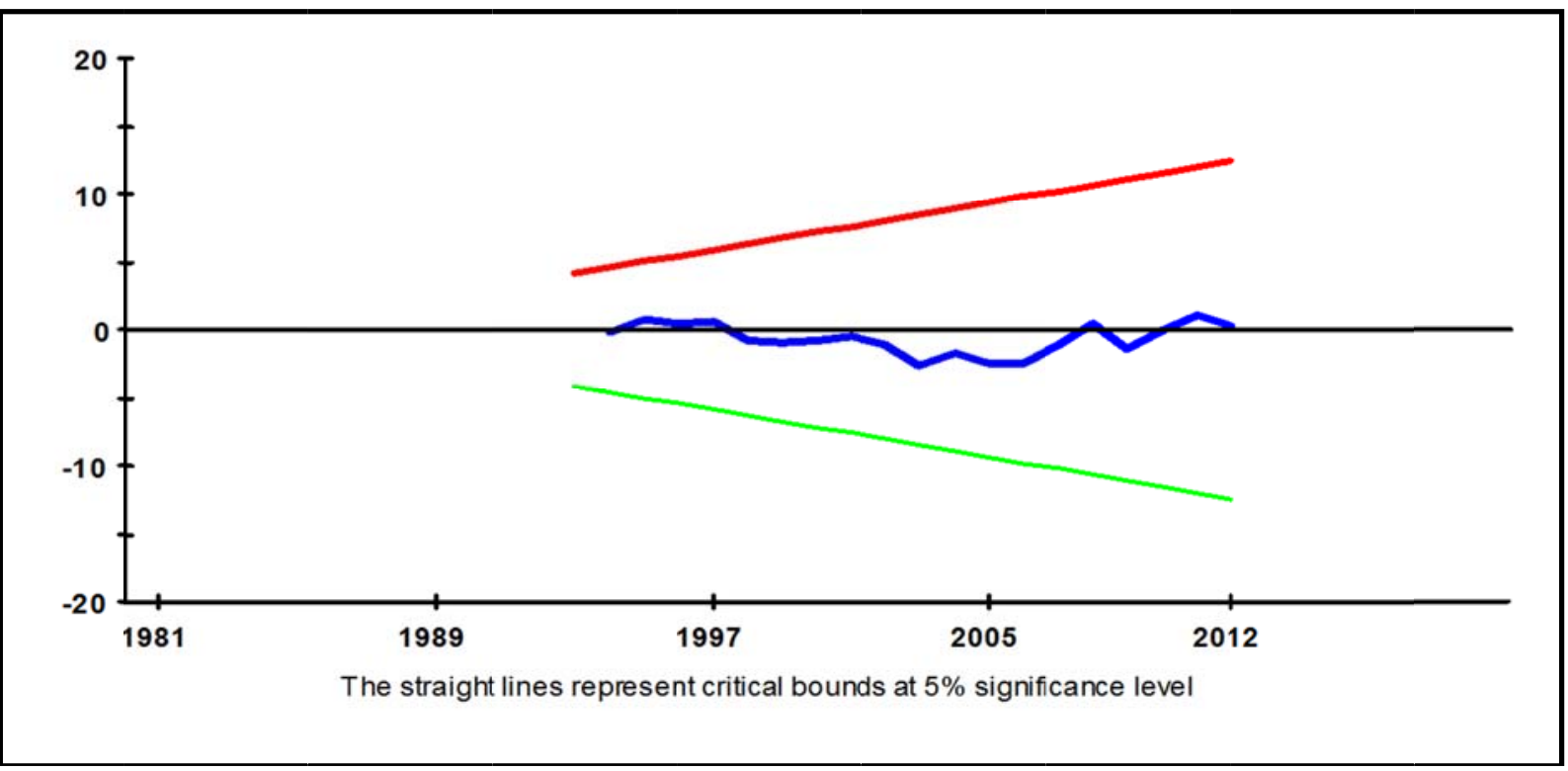

Figure 4: Plot of cumulative sum of squares of recursive residuals

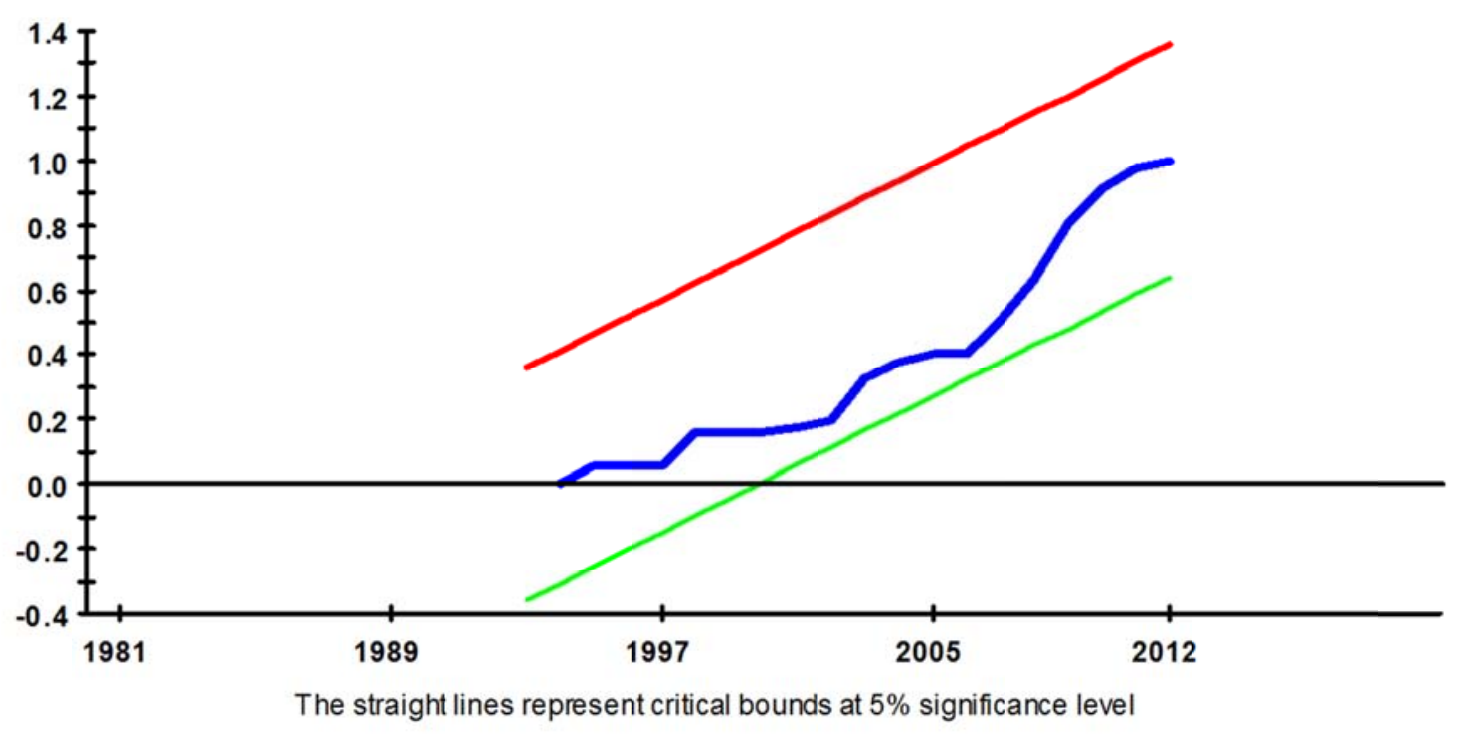

not readily available, annual data had to be resorted to. It will, therefore, be interesting to compare the results of future research studies employing more data points and/or quarterly data. Second, the model may have been under-specified, a constraint that is related to data limitation. The model had only five independent variables. There are other variables that could have been included in the estimation of the model, including macroeconomic uncertainty and institutions. However, this was not possible because of the availability of only a few data points. Nevertheless, the variables incorporated in the model gave an adequate picture of the nature of the impact of financial development (bank-based and market-based) on economic growth in the country under examination. As such, it would be recommended that future studies consider other relevant variables that have not been included in this study and that they observe whether the results will differ fundamentally from those obtained for this study. Although these limitations could have affected the empirical results and evidence given in this study, it is assumed that their effects are minimal and that they have not significantly influenced the theoretical and empirical findings of this study. 


\section{CONCLUSION}

In this paper, the relative impact of bank-based and market-based financial development on economic growth in Brazil during the period from 1980 to 2012 has been examined. Although a number of studies have been conducted on this subject, the majority of previous studies were mainly based on the causal relationship between financial development and economic growth. In addition, some of the previous studies relied mainly on bank-based financial indicators to measure financial development. Very few studies have examined in detail the relative impact of both bank-based and market-based financial development on economic growth. In addition, the majority of the previous studies relied mainly on the residual-based co-integration test, associated with Engle and Granger (1987), and the maximum-likelihood test, based on Johansen (1988) and Johansen and Juselius (1990) to test for co-integration. Yet it is now known that these techniques may not be appropriate when the sample size is too small. Unlike the majority of previous studies that used individual financial development indicators, the current study employs the method of meansremoved average to construct both bank-based and market-based financial development indices. In addition, the study uses the recently developed ARDL bounds testing approach to examine this linkage. The empirical results show that there is a positive relationship between market-based financial development and economic growth in Brazil in the long run but not in the short run. The results also show that bank-based financial development in Brazil does not have a positive effect on economic growth. This applies irrespective of whether the regression analysis is conducted in the short run or in the long run. The study, therefore, concludes that it is the stock market rather than banking sector development that drives long-run economic growth in Brazil.

\section{REFERENCES}

Abu-Bader, S. and Abu-Qarn, A. 2008. Financial development and economic growth: Empirical evidence from MENA countries. Review of Development Economics 12 (4): 803-817.

Adjasi, C. K. D. and Biekpe, N. B. 2006. Stock market development and economic growth: The case of selected African countries. African Development Review 18 (1): 144-161.

Ahmed, S. M. and Ansari, M. I. 1998. Financial sector development and economic growth: The South-Asian experience. Journal of Asian Economics 9 (3): 503-517.

Akinlo, A. E. and Akinlo, O. O. 2009. Stock market development and economic growth: Evidence from seven
sub-Sahara African countries. Journal of Economics and Business 61 (2): 162-171.

Akinlo, A. E. and Egbetunde, T. 2010. Financial development and economic growth: The experience of 10 sub-Saharan African countries revisited. The Review of Finance and Banking 2 (1): 17-28.

Allen, F. and Gale, D. 1999. Diversity of Opinion and the Financing of New Technologies. Journal of Financial Intermediation 8: 68-89.

Ang, J. B. and McKibbin, W. J. 2007. Financial liberalization, financial sector development and growth: Evidence from Malaysia. Journal of Development Economics 84 (1): 215-233.

Awojobi, O. 2013. Does trade openness and financial liberalization foster growth? International Journal of Social Economics 40 (6): 537-555.

Bekaert, G., Harvey, C. R. and Lundblad, C. 2004. Does financial liberalization spur growth? Journal of Financial Economics 77 (1): 3-55.

Bernard, A. U. and Austin, A. 2011. The role of stock market development on economic growth in Nigeria: A timeseries analysis. African Research Review 5 (6): 213-230.

BM\&FBovespa. 2012. Various Issues. (Online) Available from <http://www.bmfbovespa.com.br/en-us/home. aspx?idioma=en-us $>$ (Accessed October 16, 2012).

Bolbola, A. A., Fatheldina, A. and Omranb, M. M. 2005. Financial development, structure, and economic growth: The case of Egypt, 1974-2002. Research in International Business and Finance 19: 171-194.

Buffie, E. F. 1984. Financial repression, the new structuralists, and stabilisation policy in semi-industrialized economics. Journal of Development Economics 14: 305-22.

Calderon, C. and Liu, L. 2003. The direction of causality between financial development and economic growth. Journal of Development Economics 72 (1): 321-334.

Caporale, G. M., Howells, P. G. A. and Soliman, A. M. 2003. Stock market development and economic growth: The causal linkage. Journal of Economic Development 29 (1): 33-50.

Carneiro, D. D., Werneck, R. L. F., Garcia, M. G. P., Bonomo, M. A. (1993). Strengthening Brazil's financial economy, Inter-American Development Bank, Working Paper 142.

Casselli, F., Esquivel, G. and Lefort, F. 1996. Reopening the convergence debate: A new look at cross-country growth empirics. Journal of Economic Growth 1 (3): 363-389.

Christopoulos, D. K. And Tsionas, E. G. 2004. Financial development and economic growth: evidence from panel root and cointegration tests. Journal of Development Economics 73: 55-74.

De Gregorio, J. and Guidotti, P. E. 1995. Financial development and economic growth. World Development 23 (3): 433-448. 
Demirguc-Kunt, A. and Levine, R. 1996. Stock market development and financial intermediaries: Stylized facts. World Bank Economic Review 10 (2): 291-321.

Demirguc-Kunt, A. and Levine, R. 2001. Bank-based and market-based financial systems: Cross-country comparisons. In: Demirguc-Kunt, A. and Levine, R. (Eds.) Financial Structure and Economic Growth: A Cross- Country Comparison of Banks, Markets, and Development. MIT Press, Cambridge, MA: 81-140.

Engle, R. F. and Granger, C. J. 1987. Cointegration and Errorcorrection - Representation, Estimation and Testing. Econometrica 55 (2): 251-278.

Fama, E. F. 1990. Stock returns, expected returns, and real activity. Journal of Finance 45: 1089-1108.

Gambacorta, L., Yang, J. and Tsatsaronis, K. 2014. Financial structure and growth. Bank of International Settlement Quarterly Review March: 21-35.

Gelb, A. H. 1989. Financial policies, growth, and efficiency. In Policy Research Working Paper Series: World Bank

Ghali, K. H. 1999. Financial development and economic growth:TheTunisian experience. Review of Development Economics 3 (3): 310-322.

Ghirmay, T. 2004. Financial development and economic growth in sub-Saharan African countries: Evidence from time series analysis. African Development Review 16 (3): 15-432.

Goldsmith, RW. 1969. Financial Structure and Development. New Haven, CT: Yale University Press.

Güryay, E., Şafakli, O. V. and Tüzel, B. 2007. Financial development and economic growth: Evidence from Northern Cyprus. International Research Journal of Finance and Economics 8: 57-62.

Hoshi, T., Kashyap, A. and Scharfstein, D. 1990. The role of banks in reducing the costs of financial distress in Japan. Journal of Financial Economics 27 (1): 67-88.

International Finance Corporation. 1991. Emerging Stock Markets Factbook 1991. (Online) Available from <http://www- wds.worldbank.org/external/default/ WDSContentServer/IW3P/IB/1999/12/30/000178830 _98101901500371/Rendered/INDEX/multi_page.txt> (Accessed January 6, 2014).

International Monetary Fund, 2013. Brazil: Technical Note on Stress Testing the Banking Sector. IMF Country Report $13 / 147$.

Johansen, S. 1988. Statistical analysis of cointegration vectors. Journal of Economic Dynamics and Control 12: 231-254.

Johansen, S. 1991. Estimation and hypothesis testing of cointegration vectors in Gaussian vector Autoregressive Models. Econometrica 59: 1551-1580.

Johansen, S. and Juselius, K. 1990. Maximum likelihood estimation and inference on cointegration with applications to the demand for money. Oxford Bulletin of Economics and Statistics 52: 169-210.
Kar, M., Peker, O. and Kaplan, M. 2008. Trade liberalization, financial development and economic growth in the long term: The case of Turkey. South East European Journal of Economics and Business 3 (2): 25-38.

Kargbo, S. M. and Adamu, P. A. 2009. Financial development and economic growth in Sierra Leone. West African Journal of Monetary and Economic Integration 9 (2): 30-61.

King, R. G. and Levine, R. 1993a. Finance and growth: Schumpeter might be right. Quarterly Journal of Economics 108 (3): 717-737.

King, R. G. and Levine, R. 1993b. Finance, entrepreneurship, and growth: Theory and evidence. Journal of Monetary Economics 32 (3): 513-542.

Levine, R. 1997. Financial development and economic growth: Views and agenda. Journal of Economic Literature 35: 688-726.

Levine, R. 1999. Law, finance, and economic growth. Journal of Financial Intermediation 8 (1/2): 36-67.

Levine, R. 2004. Finance and Growth: Theory and Evidence. National Bureau of Economic Research w10766.

Levine, R. and Zervos, S. 1996. Stock market development and long run growth. World Bank Economic Review 10 (2): 323-340.

Levine, R. and Zervos, S. 1998. Stock markets banks and economic growth. American Economic Review 88: 537-558.

Lucas, R. 1988. On the Mechanism of Economic Development. Journal of Monetary Economics 22 (1): 3-42.

Majid, M. S. A. 2008. Does financial development matter for economic growth in Malaysia? An ARDL bound testing approach. Journal of Economic Cooperation 29 (1): 61-82.

Masoud, N. and Hardaker, G. 2012. The impact of financial development on economic growth. Studies in Economics and Finance 29 (3): 148-173.

Mayer, C. 1988. New Issues in Corporate Finance. European Economic Review 32: 1167-1188.

McKinnon, RI. 1973. Money and capital in economic development. Washington, D.C: Brookings Institution.

Ministry of Finance, Brazil, 2012. History of the Capital Market. Investment Portal. (Online) Available from <http://www.portaldoinvestidor.gov.br/> (Accessed October 11, 2012).

Nazmi, N. 2005. Deregulation, financial deepening and economic growth: The case of Latin America. The Quarterly Review of Economics and Finance 45: 447-459.

Ndebbio, J. E. U. 2004. Financial deepening, economic growth and development: Evidence from selected subSaharan African countries. African Economic Research Consortium (AERC) Research Paper 142.

Nurudeen, A. 2009. Does stock market development raise economic growth? Evidence from Nigeria. The Review of Finance and Banking 1 (1): 15-26. 
Odedokun, M. O. 1996. Alternative econometric approaches for analysing the role of the financial sector in economic growth: Time-series evidence from LDCs. Journal of Development Economics 50 (1): 119-146.

Odhiambo, N. M. 2008. Financial depth, savings and economic growth in Kenya: A dynamic causal linkage. Economic Modelling 25: 704-713.

Odhiambo, N. M. 2009. Savings and economic growth in South Africa: A multivariate causality test. Journal of Policy Modeling 31: 708-718.

Odhiambo, N. M. 2011. Financial intermediaries versus financial markets: A South African experience. International Business \& Economics Research Journal 10 (2): 77-84.

Oludele, A., Akinboade, E. and Chanceline, K. 2015. Forthcoming. Financial development, economic growth and millennium development goals in South Africa: is there a link? International Journal of Social Economics 42 (5).

Park, J. 2012. Brazil's Capital Market: Current Status and Issues for Further Development. IMF Working Paper WP/12/224.

Pesaran, B. and Pesaran, MH. 2009. Time Series Econometrics Using Microfit 5.0. Oxford University Press, Oxford.

Pesaran, M. H. and Shin, Y. 1999. An autoregressive distributed lag modelling approach to cointegration analysis, in Econometrics and Economic Theory in the 20th Century: The Ragnar Frisch Centennial Symposium, eds. Storm, S., Cambridge University Press, Chapter 11: 1-31.

Pesaran, M. H., Shin, Y. and Smith, R. 2001. Bound Testing Approaches to the Analysis of Level Relationship. Journal of Applied Econometrics 16: 174-189.

Pollin, R. 1995. Financial Structures and Egalitarian Economic Policy Pollin, Robert. New Left Review 0.214: 26.

Ram, R. 1999. Financial development and economic growth: Additional evidence. Journal of Development Studies 35 (4): 164-174.

Robinson, J. 1952. The Rate of Interest and Other Essays. London: MacMillan.
Romer, P. 1986. Increasing returns and long-run growth. Journal of Political Economy 94 (5): 1002-1037.

Roubini, N. and Sala-i Martin, X. 1992. Financial repression and economic growth. Journal of Development Economics 39: 5-30.

Schumpeter, J. A. 1911. The Theory of Economic Development, An Inquiry into Profits, Capital, Credit, Interest, and the Business Cycle. Cambridge MA, Harvard University Press.

Shan, J. and Jianhong, Q. 2006. Does financial development 'lead' economic growth? The case of China. Annals of Economics and Finance 1: 231-250.

Shaw, E. S. 1973. Financial Deepening in Economic Development. New York: Oxford University Press.

Stern, N. 1989. The economics of development: a survey. Economic Journal 100: 597-685.

Tadesse, S. 2005. Financial development and economic performance. In: Klein, E. (Ed.) Financial institutions and development. New York: Nova Science Publishers, Inc: 1-43.

Ujunwa, A. and Salami, O. P. 2010. Stock market development and economic growth: Evidence from Nigeria. European Journal of Economics, Finance and Administrative Sciences 25: 44-53.

Van Wijnbergen, S. 1983. Credit policy, inflation and growth in a financially repressed economy. Journal of Development Economics 13: 45-65.

Wood, A. 1993. Financial development and economic growth in Barbados: Causal evidence. Savings and Development 17 (4): 379-390.

World Bank, 2012. World Bank Development Indicators. (Online) Available from <http://data.worldbank.org/topic/financial-sector $>$ (Accessed October 5, 2012).

World Bank. 2014. World Bank Development Indicators. (Online) Available from <http://data.worldbank.org/topic/financial-sector> (Accessed January 5, 2014).

Yonezawa, Y. and Azeez, A. A. 2010. Financial systems and economic performance: a cross country analysis. Global Economy and Finance Journal 3 (2) September: 107-121. 


\section{APPENDIX 1: BREAK PERIOD FOR VARIABLES UNDER PPUROOT TEST}

\begin{tabular}{|l|c|c|c|c|}
\hline Variable & \multicolumn{2}{|c|}{ Break Period of all Variables in Levels } & \multicolumn{2}{c|}{ Break Period of all variables in First Difference } \\
\hline & Without Trend & With Trend & Without Trend & With Trend \\
\hline GDP & 1989 & 1987 & 1988 & 1986 \\
\hline BFD & 1993 & 1993 & 1993 & 1993 \\
\hline MFD & 1999 & 1999 & 1995 & 1995 \\
\hline INV & 1989 & 1989 & 1989 & 1989 \\
\hline SAV & 1988 & 1988 & 1988 & 1988 \\
\hline TOP & 1998 & 1998 & 2004 & 2004 \\
\hline
\end{tabular}

